\title{
ICC and Afrocentrism: The Laws, Politics and Biases in Global Criminal Justice
}

\author{
Nwafor Ndubuisi* \\ Mukoro Benjamin Onoriode ${ }^{* *}$
}

DOI: $10.21827 / 5 b 51 \mathrm{~d} 55740 \mathrm{ab} 8$

\section{Keywords \\ INTERNATIONAL CRIMINAL COURT; AFRICA; BIAS; WITHDRAWAL; CONTINUED RELEVANCE}

\begin{abstract}
The International Criminal Court (ICC) was established to prosecute the most serious crimes of concern to the international community as a whole. However, since its inception, the Court has been wholly focused on Africa in terms of indictments and trials. This has led many Africans, including state leaders, to question the integrity of the Court. While most explanations of the ICC's focus on Africa have bordered on the political, this work attempts to find out the reason for the Court's slant towards Africa in the very Statute by which it was established. Therefore, this paper finds that of the four broad crimes that the ICC has jurisdiction to try, three (crimes against humanity, war crimes and genocide) are more likely to occur in Africa, while the fourth (the crime of aggression), will more likely be perpetrated by or at the instigation of individuals in powerful States.
\end{abstract}

\section{Introduction}

The International Criminal Court (ICC) was set up by the international community to deal with cases involving 'the most serious crimes of concern to the international community as a whole'. African countries played a very important role in bringing the Court into existence. After the adoption of the Rome Statute, which establishes the court on the $17^{\text {th }}$ of July 1998 , Senegal, an African nation, was the first to ratify the treaty. This treaty was billed to come into force after ratification by sixty (60) countries, and this condition was fulfilled with the ratification of the treaty by the Democratic Republic of Congo on the $1^{\text {st }}$ of July $2002 .^{2}$ African countries have thus been highly instrumental in the coming into being of the ICC. Against this background, one would ordinarily expect to see a picture of co-operation and a jolly relationship between the ICC and African countries. However, this is not the case. According to most African leaders and some

\footnotetext{
* Dr Nwafor Ndubuisi LLB, BL, LLM (Glasgow Caledonian, UK) PhD (Stirling, UK) (Corresponding Author) Lecturer, Faculty of law, University of Nigeria, Enugu Campus. Email: ndubuisi.nwafor@unn.edu.ng.

** Mr Mukoro Benjamin Onoriode LLB, BL, LLM (Lecturer, Faculty of Law, Novena University Ogume, Nigeria).

1 Rome Statute of the International Criminal Court (adopted 17 July 1998, entered into force 1 July 2002) 2187 UNTS 90, Article 5.

2 Avocat Sans Frontiere, Africa and the International Criminal Court: Mending Fences, July 19 2012, at <asf.be/wp-content/uploads/2012/08/ASF_UG_Africa-and-the-ICC.pdf> (accessed 21 April 2018 ), 7.
} 
observers, the ICC has cast an unfair and overbearing attention on African States. The ICC on the other hand claims that this is not the case. ${ }^{3}$

A cursory examination of the cases tried so far by the ICC would reveal that they are exclusively African in terms of both the personal and geographical coverage. The question this work seeks to confront is whether the exclusively African focus of the ICC is, as has been claimed by some, a reflection of an anti-African bias or may be explained by some other reasons. And how does the work of the ICC in Africa, whether seen as objective or unfairly biased, affect the effectiveness of the ICC as an International Criminal Court in the coming years?

Agitations by African leaders have begun to take their toll on the support base of the Court as some African States have vowed to withdraw from the Rome Statute. Such withdrawals and other forms of dissent are likely to increase unless the negative perception of the Court, which is fast spreading, is cured. This, therefore, is the aim of this paper: to remedy the progressively negative perception of the ICC with a view to preserving its relevance and existence. In order to achieve the aim of this work, it is taken as an objective to unravel the true reason for the exclusive limitation of ICC activities to Africa. This paper seeks to look beyond the usual assertions and to decipher the specific causes of the tendency of the ICC to prosecute crimes of African origin. Questions to be asked: 1 . Are there any reasons, apart from political ones, that explain the ICC's focus on Africa? 2. Does the Rome Statute contain provisions that make it more likely that crimes of African origin would be prosecuted by the ICC, as compared with crimes committed elsewhere? 3. If there are such provisions, do these provisions alone explain the ICC's exclusive pre-occupation with Africa? 4. Are there ways in which African States have contributed to making Africa the exclusive playing field of the ICC?

The scope of this work is delimited by its aim and objectives. As a result, this work focuses on the jurisdictional aspect of the ICC regime, examining the investigative and prosecutorial history of the Court against the background of general principles of individual criminal responsibility in international law, which form the conceptual framework within which the questions raised in this paper are answered. The methodology employed in this work is doctrinal in the sense that the statutory basis and actions of the Court are examined against the background of established principles of individual criminal responsibility in order to achieve the aim and objectives. This work relies on primary sources like the statutes of various international judicial institutions such as the Statute of the International Court of Justice, the statutes of ad hoc International Criminal Tribunals, and, most importantly, the Rome Statute of the ICC. This work also relies on jurist writings, as well as other secondary sources such as books, journals and internet resources. Established principles of individual criminal responsibility in international law are sifted from these sources and form the central standard against which the ICC regime is judged.

\section{Admissibility Criteria under the Rome Statute}

Under the rules of international law, in order to be admissible before an international court or tribunal, a claim has to be admissible ratione temporis, ratione personae and ratione materiae - it has to be an international claim in all of these three aspects. It has to be admissible ratione temporis, that is, it has to be ripe for international jurisdiction, which

\footnotetext{
Mbaku, JM, International Justice: the International Criminal Court and Africa, Foresight Africa: Top Priorities for the Continent in 2014, (The Brookings Institution Africa Growth Initiative 2016), ), at $<$ brookings.edu/wp-content/uploads/2016/07/03-foresight-international-criminal-court-africa-mbaku1.pdf $>$ (accessed 21 April 2018), 9-10.
} 
implies that local remedies had been exhausted. It has to be admissible ratione personae in the sense that that the claim espoused by the claimant State has to be owned by a national of that State and not by a national of the respondent State, and it has to be admissible ratione materiae in the sense that it has to be based on a prima facie breach of an international legal obligation and not on an alleged breach of municipal law. Only if these criteria are met, could one say that one was dealing with an international claim. ${ }^{4}$

Under the regime of the ICC, admissibility is determined as provided for under Article 17 of the Rome Statute. The provisions on admissibility are designed in such a way as to offer States the first opportunity with regard to the prosecution of crimes. However, if States neglect, refuse or are unable to genuinely prosecute crimes, the ICC intervenes. This is the case even where proceedings have been initiated but the ICC determines that the State is not genuinely able to prosecute or that the proceedings are not independent or impartial, or are designed to shield accused persons from justice. The power of the ICC to bypass national criminal jurisdictions is one of the reasons why States are jittery over the ICC.

China, which is not yet a member of the ICC, declared through its representative at the $3^{\text {rd }}$ Plenary Meeting of the Rome Conference of 16 June 1998 that it does not welcome the idea of a court that would be 'a tool for political struggle or a means of interfering in other countries' internal affairs, and that the Court should be mindful of the need to avoid encroachment on 'the principal role of the United Nations, and in particular of the Security Council, in safeguarding world peace and security'. China deemed the principle of complementarity as 'the most important guiding principle of the [Rome] Statute', which should be 'fully reflected in all its substantive provisions and in the work of the Court; hence, the ICC would be able to exercise jurisdiction only with the consent of the countries concerned'. ${ }^{5}$

The controversy that followed the ICC warrant issued for the arrest of Saif alIslam, son of the late Libyan leader Muammar Gaddafi, revolved around the issue of complementarity. ${ }^{6}$ On 26 February 2011, the UN Security Council adopted Resolution 1970 by a vote of $15-0$, referring the situation in Libya to the ICC in accordance with Chapter VII of the UN Charter and Article 13(b) of the Rome Statute. On 27 June, the ICC judges authorised three arrest warrants related to the Libya investigation, including one for Saif al-Islam Gaddafi. On the same day, the court directed the ICC Registrar to prepare a request for the arrest and surrender of the three suspects, which was subsequently transmitted, with the arrest warrants, to the Libyan authorities on 4 July .? On 18 November 2011, Gaddafi was captured by members of the militia group, Abu Bakr al-Siddiq. The Libyan factional government based in Tripoli sought the trial of Saif Gaddafi in Libya. On 1 May 2012, the Government of Libya challenged the admissibility of the case concerning Saif Al-Islam Gaddafi before Pre-Trial Chamber I. On 31 May 2013, the Pre-Trial Chamber I rejected the challenge to the admissibility of the case against Saif Al-Islam Gaddafi. The Judges acknowledged Libya's efforts to restore the rule of law. However, the Chamber concluded that Libya was unable to genuinely carry out the prosecution of Mr Gaddafi, and found that the evidence submitted was not

4 Ryk-Lakhman, I, The Artefact of International Jurisdiction: Concept, History and Reality, UCL Journal Of Law And Jurisprudence Blog, 19 July 2017, at <),blogs.ucl.ac.uk/law-journal/tag/admissibility> (accessed 21 April 2018).

5 Jia, BB, "China and the International Criminal Court: Current Situation", 10 Singapore Year Book of International Law (2006) 1-11.

6 International Criminal Court (ICC), The Prosecutor v Saif Al-Islam Gaddafi, ICC-01/11 -01/11.

7 Human Rights Watch, Libya: $Q \& A$ on the ICC and Saif al-Islam Gaddafi, 14 July 2017, at $<$ hrw.org/news/2012/01/23/libya-qa-icc-and-saif-al-islam-gaddafi> (accessed 21 April 2018). 
sufficient to consider that the domestic and ICC investigations cover the same case. On 21 May 2014, the ICC Appeals Chamber confirmed the decision of Pre-Trial Chamber I, declaring the case against Saif Al-Islam Gaddafi admissible. ${ }^{8}$ But in March 2014, the Tripoli Court of Assize charged Gaddafi in absentia with war crimes and crimes against humanity in relation to the killings allegedly committed during Libya's 2011 uprising. As a result, Pre-Trial Chamber I issued on 10 December 2014 a finding of non-compliance by the Government of Libya owing to the non-execution of the request for cooperation transmitted by the ICC with respect to Saif Gaddafi and decided to refer the matter to the Security Council of the United Nations. The Chamber found that Libya has failed to comply with the requests by the Court: 1) to surrender Saif Al-Islam Gaddafi to the Court; and 2) to return to the Defence of Saif Al-Islam Gaddafi the original documents that were seized by the Libyan authorities from the former Defence counsel for Saif AlIslam Gaddafi in June 2012 in Zintan, and to destroy any copies thereof.

The Chamber emphasized that its decision was only based on the objective failure to obtain cooperation. It was not intended to sanction or criticize Libya but solely to seek the assistance of the Security Council to eliminate impediments to cooperation. ${ }^{9}$ In spite of the Pre-Trial Chamber I's finding, the Libyan Court of Assize on 28 July 2015 convicted Gaddafi on all charges and sentenced him to death by firing squad. However, the decision of the Court of Assize was not followed by the Abu Bakr al-Siddiq group, which refused to surrender Gaddafi to the Libyan authorities. ${ }^{10}$ Saif was released in June 2017 as part of a pardon issued by the Libyan parliament, which is based in the country's eastern region. ${ }^{11}$

Meanwhile, on 11 October 2013, Pre-Trial Chamber I decided that the case against Abdullah Al-Senussi, one of the three suspects, was inadmissible before the ICC as it was currently subject to domestic proceedings conducted by the competent Libyan authorities and that Libya is willing and able to genuinely carry out such investigation. On 24 July 2014, the Appeals Chamber unanimously confirmed Pre-Trial Chamber I's decision, declaring the case against Abdullah Al-Senussi inadmissible before the ICC. Proceedings against Abdullah Al-Senussi before the Court hence came to an end. ${ }^{12}$

This case illustrates how complex questions of complementarity operate in reality. The case also exposes the politics that may be intertwined with the work of the ICC in sensitive cases. It has often been rumoured that the Gaddafis had secret relations with high-profile Western governments and individuals, who they have an interest in ensuring that some of their dealings are kept secret. In the case involving Saif Gaddafi, an official of the ICC was at the centre of an alleged attempt to interfere with his trial. When an ICC legal team visited Saif in Zintan where he was being held by the Abu Bakr Battalion, one of the lawyers, Melinda Taylor (appointed by the ICC as Saif's defence attorney), was detained by the militias on grounds of allegations that she had attempted to pass documents from Mohammed Ismail, Saif's fugitive right-hand man, to Saif. The militias insisted that she discloses the whereabouts of Mohammed Ismail before she was

8 ICC, Case Information Sheet, The Prosecutor v Saif Al-Islam Gaddafi, ICC-01/11-01/11, 14 July 2017, at $<$ icc-cpi.int/libya/gaddafi/Documents/GaddafiEng.pdf> (accessed 21 April 2018).

$9 \quad I d$.

10 Trial International, SAIF AL-ISLAM Gaddafi, 14 July 2017https://trialinternational.org/latest-post/saifal-islam-gaddafi/, at <trialinternational.org/latest-post/saif-al-islam-gaddafi/> (accessed 21 April 2018).

11 Independent, Saif Al-Islam: Gaddafi's Son Released after More Than Five Years of Detention, 10 June 2017, at <independent.co.uk/news/world/middle-east/saif-al-islam-released-gaddafi-son-more-than-five-yearsdetention-libya-zintan-Statement-a7784096.html> (accessed 21 April 2018).

12 Id. 
released. ${ }^{13}$ Melinda Taylor was released alongside three other ICC colleagues after the ICC President tendered an apology. By that time, she had spent weeks in detention. ${ }^{14}$

\section{Overview of the Work of the ICC}

The ICC's work has so far been limited to Africa. All situations for which warrants of arrest have been issued by the Pre-Trial Chambers, or for which prosecutions have commenced or have been completed, are African. ${ }^{15}$ A perusal of the list of defendants at the ICC would reveal all who are listed to be of exclusively African origin. ${ }^{16}$ Does this mean that these crimes do not occur on other continents? Many commentators have responded to this question by concluding that the Court is being unfair to Africa. This has also been the view of African leaders, many of whom have called for the withdrawal of African countries from the Rome Statute. This has led to the non-implementation of ICC orders in the form of arrest warrants issued against certain Africans, most notably amongst whom is Omar al Bashir, the President of Sudan. ${ }^{17}$ The first warrant for the arrest of Omar Hassan Ahmad Al Bashir was issued on 4 March 2009, and the second on 12 July 2010. The suspect is still at large. Until Omar Al Bashir is arrested and transferred to the seat of the Court in The Hague, the case will remain in the Pre-Trial stage. The ICC does not try individuals unless they are present in the courtroom. ${ }^{18}$

During the pendency of the arrest warrant for Omar Al Bashir, al Bashir has visited a number of countries in Africa as well as Jordan but has not been arrested in accordance with the obligation of these countries under the Rome Statute to assist the ICC in carrying its functions. Judges at the International Criminal Court ruled that South Africa failed in its obligations to the War Crimes Court by failing to arrest Sudan's

13 Bond, A, Glamorous Australian Lawyer held on Spying Charge after Visiting Colonel Gaddafi's Son in Prison, MAIL ONLINE, 13 June 2012 at <),dailymail.co.uk/news/article-2158568/Glamorous-Australianlawyer-held-Libya-spying-charge-visiting-Colonel-Gaddafis-son-prison.html> (availiable 21 April 2018).

14 Reuters, Al Shalchi, H, Libya Frees Detained ICC Staff after Apology, 2 July 2012, at <reuters.com/article/us-libya-icc-idUSBRE86118V20120703> (accessed 21 April 2018).

15 Udombana, N, Africa and the International Criminal Court, 13TH JUSTICE IDIGBE MEMORIAL Lecture (2012), 34.

16 Bahr Abu Garda, Mohammed Ali, Abdallah Banda, Omar al-Bashir, Jean-Pierre Bemba, Charles Blé Goudé, Muammar Gaddafi, Saif al-Islam Gaddafi, Laurent Gbagbo, Simone Gbagbo, Ahmed Haroun, Abdel Rahim Hussein, Saleh Jerbo, Germain Katanga, Uhuru Kenyatta, Tohami Khaled, Joseph Kony, Henry Kosgey, Ali Kushayb, Thomas Lubanga Dyilo, Raska Lukwiya, Ahmad al-Mahdi, Callixte Mbarushimana, Sylvestre Mudacumura, Francis Muthaura, Mathieu Ngudjolo Chui, Bosco Ntaganda, Okot Odhiambo, Dominic Ongwen, Vincent Otti, William Ruto, Joshua Sang, Abdullah Senussi.

The warrants of arrest for Omar Al Bashir list ten counts on the basis of his individual criminal responsibility under Article 25(3)(a) of the Rome Statute as an indirect (co-)perpetrator including: (i) Five counts of crimes against humanity: murder (Article 7(1)(a)); extermination (Article 7(1)(b)); forcible transfer (Article $7(1)(\mathrm{d})$ ); torture (Article $7(1)(\mathrm{f})$ ); and rape (Article $7(1)(\mathrm{g})$ ); ) perpetrator including:

1. Five counts of crimes against humanity: murder (Article 7(1)(a)); extermination (Article 7(1)(b)); forcible transfer (Article 7(1)(d)); torture (Article 7(1)(f)); and rape (Article 7(1)(g));

2. Two counts of war crimes: intentionally directing attacks against a civilian population as such or against individual civilians not taking part in hostilities (Article 8(2)(e)(i)); and pillaging (Article $8(2)(\mathrm{e})(\mathrm{v}))$; and

3. Three counts of genocide: genocide by killing (Article 6-a), genocide by causing serious bodily or mental harm (Article 6(b)) and genocide by deliberately inflicting on each target group conditions of life calculated to bring about the group's physical destruction (Article 6-(c)). See Case Information Sheet, The Prosecutor v. Omar Hassan Ahmad Al Bashir, 8 July 2017, at <icc-cpi.int/darfur/albashir/Documents/ AlBashirEng.pdf $>$ (accessed 21 April 2018).

18 ICC, Omar Al Bashir Case, The Prosecutor v. Omar Hassan Ahmad Al Bashir, ICC-02/05-01/09, 8 July 2017, at <icc-cpi.int/darfur/albashir> (accessed 21 April 2018). 
wanted president when he visited the nation for a summit of African leaders in 2015. On 28 March 2017, the Jordanian government permitted al Bashir to enter Jordan for an Arab League summit meeting that was held the following day. It did not arrest al Bashir during his stay in Jordan and for that the ICC decided to refer Jordan to the UN Security Council. Jordan entered an appeal against the decision of the ICC. Meanwhile, South Africa announced its intent to leave the court in 2015, after the public disagreement with the court over the Bashir incident. ${ }^{19}$ In the same vein, African leaders have adopted a strategy calling for a collective withdrawal from the International Criminal Court. The non-binding decision was taken behind closed doors near the end of an African Union summit. ${ }^{20}$ Earlier, in 2016, South Africa, Burundi and the Gambia, all announced plans to leave the Court, leading to concerns that other States would follow. ${ }^{21}$ In the case of South Africa, a high court ruled at the instance of the opposition party, Democratic Alliance (DA), that the withdrawal process was null and void because it was not debated in parliament. The ANC government, however, said it was determined to follow through the withdrawal process. In the Gambia, after the exit of former ruler Yahya Jammeh, the decision earlier made to quit the ICC was reversed. Although the resolution calling for the withdrawal of African Union (AU) members from the ICC is not binding and is opposed by certain countries like Nigeria and Senegal, ${ }^{22}$ it raises issues that must be seriously considered by the ICC if it plans to maintain and grow its already diminishing legitimacy.

\section{Why the ICC Focuses on Africa}

The ICC's African bias is frequently attributed to the political inclination of the Court. This assertion is not denied here as it is well known to many scholars of international law that it has so far been impossible to separate international law from politics. However, what this section of the paper seeks to achieve is to reveal other reasons inherent in the provisions of the Rome Statute before turning to the political factor, using the political element as a connecting thread to explain why certain provisions are designed the way they are.

The jurisdiction of the ICC is limited to four crimes: genocide, crimes against humanity, war crimes and the crime of aggression. An examination of the elements of the first three crimes would reveal that these crimes are less likely to occur in affluent societies with highly organised social and political structures, which have evolved over a long period of time. In contrast, some African states with unorganised social and political systems are more likely to witness upheavals that follow these crimes. Most African countries do not have properly built and supported legal and judicial systems to effectively prosecute perpetrators of crimes. This necessarily triggers the jurisdiction of the ICC in accordance with the principle of complementarity. Three African States with a case before the Court have themselves referred the situation to the ICC. They have themselves requested that the Prosecutor investigates the crimes committed on their

19 Powell, A, South Africa Failed Obligation by Not Arresting Sudan's Bashir, VOICE OF AMERICA , 6 July 2017, at <voanews.com/a/icc-south-africa-sudan-bashir-arrest-failure/3930865.html> (accessed 21 April 2018).

20 The Guardian, Associated Press in Addis Ababa, African Leaders Plan Mass Withdrawal from International Criminal Court, THE31 January 2017, at <theguardian.com/law/2017/jan/31/african-leaders-plan-

21 Id mass-withdrawal-from-international-criminal-court> (accessed 21 April 2018).

22 BBC News, Igunza, E, African Union Backs Mass Withdrawal from ICC, 1 February 2017, at $<$ bbc.com/news/world-africa-38826073> (accessed 21 April 2018). 
territory, thereby acknowledging their lack of capacity to investigate and prosecute these offences. $^{23}$

Of the crimes over which the ICC has jurisdiction, the crime of aggression is the one most likely to be committed by affluent countries because amongst the rank of these are hegemonic States that exercise influence and control over the affairs of other States by means of war and military interventions. However, the provisions of the Rome Statute concerning the exercise of jurisdiction apart from any other contributing factor, have made it impossible so far for persons to be prosecuted for that offence. Firstly, the ICC did not have jurisdiction over the crime of aggression until Resolution RC/Res. 6, annex 1 of 11 June 2010, which inserted Article 8 bis that defines the crime of aggression. The coming into force of this amendment was subject to ratification by 30 States Parties. ${ }^{24}$ On 26 June 2016, the State of Palestine deposited its instrument of ratification of the amendments to the Rome Statute on the crime of aggression. The State of Palestine thus became the 30th State to ratify the amendments on the crime of aggression. ${ }^{25}$ It was stipulated that the Court may begin to exercise jurisdiction over crimes of aggression only with respect to crimes committed one year after the ratification or acceptance of the amendments by 30 States Parties. In addition, a decision to be taken after 1 January 2017, by the Assembly of States Parties, with the same majority of States Parties required for the adoption of the amendment, was needed to activate the ICC's jurisdiction over the crime of aggression. ${ }^{26}$ From $4-14$ December 2017, the Assembly of States Parties held its 16th session where it resolved to activate the jurisdiction of the ICC over crimes of aggression with effect from 17 July $2018 .^{27}$

However, in spite of this decision, the ICC's jurisdiction over crimes of aggression is in reality limited and may in fact prove to be impotent for different reasons. The Rome Statute provides that States Parties may, by a declaration lodged with the Registrar, opt out of the Court's jurisdiction over the crime of aggression. ${ }^{28}$ The jurisdiction of the court shall also not extend to crimes of aggression committed by nationals or on the territory of non-State parties. Paragraph 2 of the activating resolution states that '...in the case of a State referral or propio motu investigation the Court shall not exercise its jurisdiction regarding a crime of aggression when committed by a national or on the territory of a State Party that has not ratified or accepted these amendments' ${ }^{29}$ This provision represents deference to the position of powerful states like the United Kingdom and France amongst others, as against that of states who wanted the ICC to have jurisdiction

${ }^{23}$ International Federation for Human Rights, ICC The International Criminal Court's First Years, 2009 No.516a, 15; The cases involving Cote d'Ivoire, Mali and Uganda all originated from State referrals.

24 Article 15 bis (2); The exclusion of aggression was in recognition of the differing nature of the crime, which is based on jus ad bellum (the legality of the war itself), while crimes against humanity, genocide and war crimes are based on jus in bello (the legality of the conduct of the war). The Permanent Members of the Security Council also saw the enactment of such an offence within the ICC framework as contrary to their interests as hegemonic States which are often accused of aggression. See Scharf, MP, "Universal Jurisdiction and the Crime of Aggression", 53(2) Harvard International Law Journal 358, at $<$ harvardilj.org/wp-content/uploads/2012/10/HLI201.pdf> (accessed 21 April 2018), 361.

25 ICC, State of Palestine becomes Thirtieth to Ratify the Kampala Amendments on the Crime of Aggression, 9 July 2017, at <icc-cpi.int/legalAidConsultations?name=pr1225> (accessed 21 April 2018).

26 The Global Campaign for Ratification and Implementation of the Kampala Amendments on the Crime of Aggression, Conditions for Action by the ICC, 9 July 2017, at <crimeofaggression.info/role-of-theicc/conditions-for-action-by-the-icc> (accessed 21 April 2017).

27 ICC, 'Trying Individuals for Genocide, War Crimes, Crimes against Humanity and Aggression', at <https://www.icc-cpi.int/Pages/item.aspx?name=pr1350> (accessed 10 March 2018).

28 Article 15 bis (4).

29 Resolution ICC-ASP/16/Res.5 
where crimes of aggression are committed by nationals or on the territory of States Parties that did not ratify the Kampala amendments. ${ }^{30}$

Thus, while the jurisdiction of the ICC is independent of State consent in respect of the other three crimes, the possibility of opting out of the Court's jurisdiction over aggression makes its jurisdiction in respect of this crime dependent on the decision of States Parties not to opt out- a form of negative or passive consent. Theoretically, it is possible to bypass this passive consent by means of a Security Council referral made under Chapter VII of the UN Charter. In that case, the ICC would be acting not pursuant to its own jurisdiction but pursuant to the powers of the Security Council. However, since the permanent members of the Security Council form part of the States whose citizens are most likely to be indicted for this crime, it may be assumed that this mechanism would not be frequently utilized. Where the interests of one of the permanent members are not at stake, it is highly probable that those of one of their allies would be. Generally, the records have shown that the P5 (as the UN permanent members are often called) prefer to make referrals, which are convenient to them. An example is the refusal to refer the Syrian situation to the ICC. On 22 May 2014, China and Russia vetoed a draft resolution of referral in the face of a letter sent to the Security Council with the positive signature of 57 States in favour of a referral. ${ }^{31}$ It needs to be noted at this point the persons most likely to be indicted for the crime of aggression are leaders and highranking government officials. Article 25(3) bis of the Rome Statute provides that

In respect of the crime of aggression, the provisions of this article shall apply only to persons in a position effectively to exercise control over or to direct the political or military action of a State.

This makes the crime of aggression a leader's crime and less likely that the Security Council referral mechanism would be used, considering the veto powers that the permanent members wield.

Ordinarily, Article 12 requires for the exercise of jurisdiction by the ICC, that either the State of territoriality or the State of nationality be party to the Rome Statute. This is in accordance with the normal rules on 'effects' or 'objective territorial' jurisdiction and is the case with genocide, crimes against humanity and war crimes. Thus, a citizen of a non-State party who commits genocide, war crimes or crimes against humanity on the territory (or having an effect on the territory) of a State Party is subject to ICC jurisdiction. This is not the case with the crime of aggression, despite the fact that aggression can, as a matter of territoriality, take place both in the State where the aggression is plotted, and in the State where it is executed. ${ }^{32}$

The United States, which had earlier signed the Rome Treaty, declared that it did not intend to ratify the Statute and does not have any obligation towards the ICC. On 6 May 2002, the Bush Administration announced that the United States does not intend to become a party to the Rome Statute of the International Criminal Court. In a letter to

30 Durr, B, 'The Challenges of Prosecuting Wars of Aggression', Blog of the Groningen Journal of International Law, 29 January 2018, <grojil.org/2018/01/29/the-challenges-of-prosecuting-wars-ofaggression/> (accessed 10 March 2018).

31 Couture, A, "The Politics of International Justice: the Security Council's Impact on the Independence, Effectiveness and Legitimacy of the International Criminal Court", 3(2) International Human Rights Internship Working Paper Series, McGill Centre For Human Rights And Legal Pluralism, 2015, 15-16.

32 Clark, RS, "Amendments to the Rome Statute of the International Criminal Court Considered at the First Review Conference on the Court, Kampala", 31 May - 11 June 2010, 2 GOETTINGEN JOURNAL OF INTERNATIONAL Law (2010) 689, 705. 
Kofi Annan, the Secretary-General of the United Nations, it was stated that 'the United States does not intend to become a party to the treaty,' and that 'accordingly, the United States has no legal obligations arising from its signature on 31 December 2000.' Defence Secretary Donald Rumsfeld explained that the Administration had:

a number of serious objections to the International Criminal Court - among them, the lack of adequate checks and balances on powers of the [Court's] prosecutor and judges; the dilution of the U.N. Security Council's authority over international criminal prosecutions; and the lack of any effective mechanism to prevent politicized prosecutions of American service members and officials. ${ }^{33}$

The Bush Administration concluded bilateral immunity agreements (BIAs) known as 'Article 98 agreements,' with most States parties to exempt US citizens from possible surrender to the ICC. These agreements are named for Article 98(2) of the Statute, which bars the ICC from asking for surrender of persons from a State party that would require it to act contrary to its international obligations. The US government is prohibited by law from providing material assistance to the ICC in its investigations, arrests, detentions, extraditions, or prosecutions of war crimes, under the American Service Members' Protection Act of 2002 (ASPA) (PL, 107-206, Title II). The prohibition covers, among other things, the obligation of appropriated funds, assistance in investigations on US territory, participation in UN peacekeeping operations, unless certain protections from ICC actions are provided to specific categories of personnel and the sharing of classified and law enforcement information. ${ }^{34}$ The succeeding Obama administration had a friendlier relationship with the ICC, even ensuring that the United States attended the Kampala Conference, as an observer nation. ${ }^{35}$

Russia also said it was formally withdrawing its signature from the founding statute of the International Criminal Court, a day after the court published a report classifying the Russian annexation of Crimea as an occupation. Russia denounced the ICC's work as 'one-sided and inefficient.' Russia signed the Rome statute in 2000 and cooperated with the Court but had not ratified the treaty and thus remained outside the ICC's jurisdiction. ${ }^{36}$ The absence of major powers like the United States and Russia from the ICC fold means that actions and situations involving these hegemonic states, which usually have far-reaching impacts, are excluded from the Court's direct scrutiny. The only avenue for holding them accountable is through the UN Security Council where they also have a strong influence and veto powers. This limits the ICC's jurisdiction to less powerful countries like African states that in turn feel victimised and are spurred to quit the Court. This portends a threat to the continued relevance of the Court.

33 Bradley, C, "US Announces Intent not to Ratify International Criminal Court Treaty", 7 (7) American Society Of International Law (2002), at <asil.org/insights/volume/7/issue/7/us-announces-intent-notratify-international-criminal-court-treaty> (accessed 21 April 2018).

34 Section 2015 of ASPA (22 USC 7433, the Dodd Amendment), however, provides an exception to these provisions. Nothing in this title shall prohibit the United States from rendering assistance to international efforts to bring to justice Saddam Hussein, Slobodan Milosevic, Osama bin Laden, other members of Al Qaeda, leaders of Islamic Jihad, and other foreign nationals accused of genocide, war crimes or crimes against humanity.

35 Arieff, A, et al., International Criminal Court Cases in Africa: Status and Policy Issues, CONGRESSIONAL RESEARCH Service, 22 July 2011, at <fas.org/sgp/crs/row/RL34665.pdf.> (accessed 21 April 2018).

36 The Guardian, Walke, S and Bowcott, O, Russia Withdraws Signature from International Criminal Court Statute, 16 November 2016, at <theguardian.com/world/2016/nov/16/russia-withdraws-signaturefrom-international-criminal-court-statute $>$ (accessed 21 April 2018). 
Where the Prosecutor acts in respect of the crime of aggression, he or she must first ascertain, by means of a notification, whether the Security Council has determined that any particular State has committed a crime of aggression before proceeding with an investigation. ${ }^{37}$ Where such a determination has been made, the prosecutor may proceed with an investigation and where none has been made, he/she may also proceed with an investigation, but only after the expiration of six months following the date of notification. ${ }^{38}$ In any case, the Security Council may request the Court to defer investigation or prosecution, as pursuant to Article 16 Rome Statute. Such a deferral shall last for a period of 12 months, renewable under the same conditions as the initial request. ${ }^{39}$ However, consistent with the existing Rome compromise, contained in Article 16 of the Statute, a single member of the Permanent Five members of the Security Council cannot stop an investigation or prosecution process by exercising a veto. It is only where there are nine supporting votes comprising the votes of all five permanent members and four votes of non-permanent members that proceedings may be stopped. ${ }^{40}$ In July 2009, the African Union took a decision not to co-operate with the ICC regarding the arrest warrant issued against the Sudanese President Omar al Bashir while also listing a number of issues it wanted States Parties to consider at the May 2010 Kampala Review Conference among which was a review of the Security Council's referral and deferral powers under Articles 13 and 16 respectively. ${ }^{41}$

Apart from these factors that are inherent in the provisions of the Rome Statute, there is another possible reason why the ICC prefers to concern itself with offences committed on the African continent. This has to do with the bringing into being of the statute. Every law enforcement institution must legitimise its exercise of jurisdiction over parties. Legitimacy helps to ensure voluntary compliance with institutional requirements and to receive the support necessary for effective discharge of responsibilities. The ICC has the need like any other institution to practically legitimise its existence by dutifully carrying out its responsibilities. While pursuing this need, it must have searched for the forum most likely to welcome its jurisdiction. Given Africa's record of early ratification, producing the first and sixtieth State that allowed the Statute to come into force, and support for the Statute, the Court probably saw Africa as a suitable testing ground. Therefore, African countries, by supporting the establishment and activation of the ICC, may have unwittingly presented themselves as lab rats to the ICC. Out of 123 States Parties to the Rome Statute, 33 are African, 19 are Asia-Pacific, 18 are from Eastern Europe, 28 are Latin American and Caribbean and 25 are from Western Europe and other places.

However, even though the European Union has also been a major supporter of the ICC, mandating assistance to the Court in co-operation agreements such as the Cotonou Agreement, activities of the Court in Europe have so far been limited to the investigation of the Russo-Georgian conflict commenced in 2015 with no indictments yet as at the time of writing. Although armed conflicts have been more prevalent in Africa than in other regions (with perhaps the exception of the Middle East); other parts of the

37 Rome Statute of the International Criminal Court (adopted 17 July 1998, entered into force 1 July 2002) 2187 UNTS 90, Article 15 bis (6).

38 Id. Article 15 bis (7) and (8).

39 By a resolution adopted under Chapter VII of the United Nations, Charter of the United Nations (1945) 1 UNTS XVI (UN Charter).

40 Clark, supra $n t 32$ at 706.

41 Tendayi Achiume, T, The African Union, the International Criminal Court, and the United Nations Security Council, Irvine School of Law ICC-UNSC Workshop 2012, at < councilandcourt.org/files/2012/11/ ICC-AU-UNSC-Position-Paper.pdf> (accessed 21 April 2018), 3. 
world like Asia, the Caribbean and even Europe have also witnessed armed conflicts since the ICC Statute came into force in 2002. Similarly, the ICC prosecutor's request to investigate the Afghanistan conflict is the only one of such in the Middle East and Asia. The absence of ICC activity in relation to Middle-Eastern conflicts is particularly curious. As the major actors in these conflicts usually involve powerful hegemonic states, lack of ICC scrutiny tends to support arguments that the ICC deliberately avoids meddling in the affairs of some select States. Also, preliminary examinations with respect to Colombia, Iraq-UK, Ukraine and Palestine have not yet resulted in requests to investigate. Having said this, it must be added that in its search for practical legitimacy, every institution has the duty to be fair to all stakeholders, seeking to cover the whole field and to carry out their operations without fear or favour. The ICC's work so far is reminiscent of old injustices perpetrated against Africans and the African continent.

Indeed, the fact that Africa is perceived as a weak continent is often capitalized upon politically by more powerful countries, which often use the instrument of supposedly independent and non-aligned international institutions to arm-twist African leaders and States. This is made even easier in the context of the ICC, having in mind the other factors discussed above which predispose African situations to being subject to ICC jurisdiction.

\section{The Effect of the ICC's Afrocentrism on its Global Acceptance}

The fact that the ICC has failed to operate outside the African continent may have a range of effects on its ability to properly carry out its functions in the future. For a judicial body to be widely accepted, it has to be perceived as being impartial, dispensing justice equitably with respect to both the weak and the powerful. However, with reference to the ICC's African bias, it appears to be functioning where it is easiest and politically expedient for it to function, thereby enforcing justice with respect to the weak and to the exclusion of the powerful. The suspicion this approach has aroused among African leaders will be seen elsewhere in the future as the Court begins to take tentative steps outside the African continent (probably partly triggered by criticisms about its exclusive focus on Africa) with an on-going investigation concerning the situation in Georgia, a pending request for investigation with respect to Afghanistan and preliminary examinations with respect to Colombia, Ukraine, Iraq-UK and Palestine. The partiality of the Court would be cited as a reason not to co-operate. This is more likely as the ICC has been systematically ignoring contentious issues around the world and it would be difficult to justify its future interest in any particular case unless it is endowed with jurisdiction by means of State referral. Security Council referrals are also likely to be highly controversial in the future considering the number of cases the Security Council has overlooked so far. As a matter of fact, the only Security Council referrals have occurred with respect to African States.

Opposition to the ICC would take different forms. Already, the African Union has passed a non-binding resolution calling for the withdrawal of all its members from the ICC. This followed individual display of resentment by different African States, some of which had earlier vowed to quit the ICC. If these withdrawals, whether individual or bloc, should increase, the ICC would be at the risk of total collapse. Non-compliance with treaty obligations has already been witnessed with regard to ICC arrest warrants due to the Court's poor perception by African States. Omar Al Bashir has travelled to a number of countries who are States Parties to the Rome Statute without being arrested. This is contrary to Article 86 of the Rome Statute, which places an obligation on States Parties to assist the Court in carrying out its operations. The article reads as follows: 
States Parties shall, in accordance with the provisions of this Statute, cooperate fully with the Court in its investigation and prosecution of crimes within the jurisdiction of the Court.

Once an investigation is initiated by the Prosecutor, duties arise on the part of States Parties to co-operate with requests from the ICC. It is worthy of note that the ICC demands co-operation by means of requests and non-binding orders. ${ }^{42}$ It should be recalled that the ICC has no enforcement machinery of its own, and if this trend continues, it would be reduced to a lame duck. ${ }^{43}$ With African countries breaking ties with the ICC, they will no longer complement the ICC's jurisdiction. The ICC on its own part will not be able to operate in Africa because it lacks its own enforcement machinery. ${ }^{44}$ This would not be in the interest of justice as this might have an overall effect of encouraging impunity.

The ICC also relies on the financial contributions of members. Therefore, if members refuse to fulfil their financial commitments as a means of showing their displeasure with the way the Court conducts its business, then it may become very difficult for it to function or it may have to rely on financing from a few nations, which might have serious consequences for the independence of the Court. As a matter of fact, eyebrows have already been raised over the European, NGO and individual financial contributions to the Court. Concerns have been expressed about the ICC's acute financial dependence upon Western European funding corrupting the Court's independence. The American commentator, John Rosenthal, states that, 'it is a self-evident principle that the independence and hence impartiality of a court is only as sure as the independence of its financing. ${ }^{45}$ The ICC says it is financed by contributions from its States Parties. The amount payable by each State party is determined using the same method that is applied by the United Nations - each State's contribution is based on the country's capacity to pay, which reflects factors such as national income and population. The maximum amount a single country can pay in any year is limited to $22 \%$ of the Court's budget. Despite the fact that the Court theoretically sets a cap on funding at $22 \%$ of its budget from any one country, a large share of its 2009 budget came from EU member countries. The EU, through its Member States, paid 60\% of the 2009 budget of EUR 94.17 million. If the contributions of EU Member States and potential member states are added, the European contribution rises up to $63 \%{ }^{46}$ Although the EU cannot be indicted for carrying a large share of the ICC's financial burden, as this is only a reflection of its numerical representation and the economic strength of EU countries, it does give the EU countries a position of influence in the affairs of the ICC. Therefore, it would be in the interest of the ICC to work out a more balanced contribution scheme, perhaps towing the line of the recommendation made in the following section.

42 Seils, $\mathrm{P}$ and Wierda, M, The International Criminal Court and Conflict Mediation, International Center For Transanational Justice 2005, at <ictj.org/sites/default/files/ICTJ-Global-ICC-Mediation-2005English.pdf> (accessed 21 April 2018), 6.

43 See Part 9 (Article 86-102) of the Rome Statute of the International Criminal Court (adopted 17 July 1998, entered into force 1 July 2002) 2187 UNTS 90 dealing with International Co-operation and Judicial Assistance.

44 Makumbe, D, "African Response to the International Criminal Court. Implications for International Legal Justice", 20(8)(IV) IOSR Journal of Humanities and Social Science (2015) 16, 22.

45 African Business Magazine, Who Pays for the ICC (Oct. 1, 2011), at <africanbusinessmagazine.com/ uncategorised/who-pays-for-the-icc/> (accessed 21 April 2018).

46 African Business Magazine, Who Pays for the ICC (Oct. 1, 2011), at <africanbusinessmagazine.com/ uncategorised/who-pays-for-the-icc/> (accessed 21 April 2018). 
Unless the concerns noted in this work are addressed, the ICC will ultimately become moribund as it will be seen as an instrument of oppression and manipulation. As it is, the Rome Statute is increasingly assuming, in the eyes of African States, the same form as the colonial agreements made between Europeans and African leaders that ultimately paved the way for the colonisation of Africa. The ICC is increasingly being perceived as an institution from which to seek emancipation. As has been previously stated, this perception will continue to spread within and beyond Africa if the Court does not change certain aspects of its operations.

\section{Recommendations and Conclusion}

The ICC must begin to take advantage of the ample opportunities that are abound in the world today to demonstrate that it is not an International Criminal Court for Africa. It must begin to show that it is capable of functioning independently and fearlessly. This would mean a more even geographical spread of its operations, subject to the frequency of situations that require its attention in different parts of the world, as it has begun to do with the investigation of the Russo-Georgian crisis and preliminary examinations in Colombia, Iraq-UK, Ukraine and Palestine. Having said this, it is less likely to achieve a better balance in the distribution of ICC operations through the mechanism of State referral. This is because advanced countries are less prone to voluntarily refer matters whether domestic or international to the ICC. These nations would rather handle their own affairs without interference from other parties. The same goes for the Security Council whose referrals would most likely be constrained to affairs concerning less dominant States as most powerful States are either permanent members of the Council or have close alliances with the permanent members. For instance, despite the intensity of the Syrian crisis, the ICC has failed to intervene. China had already vetoed three draft resolutions on Syria in the Security Council as of December 2012 and supported the option of dialogue with the Assad regime rather than coercion and punishment. It is therefore unlikely that either China or Russia will consent to an ICC referral concerning their allies in Syria. ${ }^{47}$ The same goes for the other permanent members of the Security Council. This means that much rests on the Prosecutor and the Pre-Trial Division. The Prosecutor must be bold enough to consider situations all around the world and the PreTrial Division must give the necessary approvals where all stipulated pre-conditions have been met.

African States on their own part must shore up their local capacities to effectively prosecute genocide, crimes against humanity, war crimes and the crime of aggression. It is the inability to genuinely prosecute, combined with sheer unwillingness in some cases that predisposes African situations to adjudication by the ICC. Capacity building is also necessary at the regional stage but capacity development at national levels should be seen as a more urgent need than that at the regional level of the African Union. This is because a complementary relationship does not exist between the AU and the ICC but between the ICC and States Parties. Therefore, the attempt by the AU to set up a court which would handle cases of human rights abuses in Africa will not have a direct impact on ICC determinations whether to prosecutes crimes or not. ${ }^{48}$ Notwithstanding, if such

47 The Diplomat, Wuthnow, J, China and the ICC, (7 December 2012), at <thediplomat.com/2012/12/ china-and-the-icc/> (accessed 21 April 2018).

48 In February 2010, pursuant to a decision taken by the African Union (AU) Assembly a year earlier, the AU Commission appointed consultants to work on drafting an amended protocol on the Statute of the proposed African Court of Justice and Human Rights. The draft amended protocol, amongst other key issues, provides for the expansion of the jurisdiction of the African Court to deal with specific criminal matters. On 24 June 2014, the Assembly of the African Union adopted the draft protocol clothing the 
an African court is able to function effectively and does not prosecute crimes with the intent of shielding the perpetrators ${ }^{49}$ then the ICC, although it may not be in a complementary relationship with such a court, would most likely defer to the court's jurisdiction. It would be to the overall benefit of Africa if the AU is able to develop a strong and effective criminal justice regime.

Concerning the crime of aggression, it must be admitted that there are situations that truly call for intervention by States in the territory of other States with or without the agreement of States constituting a majority of the members of the UN. This is because with the politics of the United Nations, there may be situations where it is impossible to agree on an intervention despite a genuine need for such an action from the point of view of an interested State. For instance, the Arab bloc of the United Nations would hardly ever agree to a Western intervention in any Arab nation no matter how justified such an intervention might be. This is why the provisions on the crime of aggression have been formulated this way. They are a product of a compromise reached at the Kampala Conference, where the amendments relating to the crime of aggression were adopted. It would be impracticable to attempt a total harmonisation of the rules guiding the exercise of jurisdiction over the crime of aggression in order to make them the same as those guiding the exercise of jurisdiction over the other crimes as they are currently conceived. What is more realistic is to lay a set of rules or conditions that must be met for an intervention not to be construed as a crime of aggression. Even so, the crime of aggression will continue to remain controversial, and politics, not law alone, will continue to be a major factor in determining which particular case of intervention is investigated and prosecuted by the ICC as a crime of aggression.

As regards the influence of donors on the independence of the ICC, it is counselled that the Court should refrain from receiving donations from individuals and NGOs. Although all States might not be reasonably expected to contribute equally as a result of their varying economic strength, efforts should be made to reduce disparity by ensuring that States are given the opportunity to participate financially to the best of their ability. There should be a downward review of the upper limit of contribution by individual States and the deficit resulting from a reduction in contribution from major donors should be spread among other states. Such downward review should be progressive and increasing as more states become part of the ICC regime. It would, however, be impossible to control the total amount of donation coming from different regions of the world as this depends on the number of States Parties belonging to any particular region.

This work has shown that the inordinate attention cast on Africa by the International Criminal Court does not lend itself to a monocausal explanation but is better understood by a comprehension of interweaving factors. Therefore, this paper does not limit its explanation to the political reasons often adduced for the ICC's focus on Africa, that is, that the Court is a tool for oppression and manipulation of African leaders

African Court with criminal jurisdiction. The protocol awaits ratification by 28 AU Member States for it to come into force. Only 5 states have ratified the protocol at the time of writing this paper. See Du Plessis, M, Implications of the AU Decision to Give the African Court Jurisdiction over International Crimes, 235 Institute for Security Studies Paper (2012), at <issafrica.s3.amazonaws.com/site/uploads/Paper235AfricaCourt.pdf $>$ (accessed 21 April 2018); Cole, RJV, "Africa's Relationship with the International Criminal Court: More Political than Legal”, 14 Melbourne Journal of International Law (2013) 670, 695. See also Amnesty International, 'Malbo Protocol: Legal and Institutional Implications of the Merged and Expanded African Court' (2016), at <amnesty.org/download/Documents/AFR0130632016 ENGLISH.PDF> (accessed 25 March 2018).

49 Rome Statute of the International Criminal Court (adopted 17 July 1998, entered into force 1 July 2002) 2187 UNTS 90, Article 20(3). 
and countries by western powers. While not waving this view point aside, this work takes a deeper look at the issue and advances the view that the predilection towards the prosecution of African situations originates partly from the provisions of the Rome Statute, particularly with respect to the kinds of crimes over which the ICC may exercise jurisdiction. It points out that three of these crimes, genocide, crimes against humanity and war crimes, are more likely to occur in countries at the same developmental stage as most African countries. This point is demonstrated by the occurrence of conflicts in such other places like Afghanistan, Myanmar, Colombia, and East Timor. ${ }^{50}$ The paper explains that the conditions for exercising jurisdiction over the crime of aggression have made the ICC dormant as far as this crime is concerned with little hope that there will be frequent, if any, practical exercise of this jurisdiction in the future. The paper also acknowledges the political motivation that lies behind the ICC's Afrocentrism by questioning why the Court has been inactive in other climes with a comparable level of development as African States, and where the three crimes that were identified as likely to occur in less developed countries have as a matter of fact occurred. It concludes that unless the undeserved inclination towards African situations is rectified, the Court will continue to experience the resistance from African States, which it has already begun to witness. This uncooperative attitude will spread beyond Africa and become entrenched, leading to the ultimate redundancy and collapse of the Court. Therefore, it is of utmost importance that the suggestions proffered in this work, as well as other adaptations that will be needed as developments unfold and different persons engage this problem, be implemented if at all the ICC is to remain in existence.

\author{
www.grojil.org
}

50 Myanmar, Colombia and East Timor are parties to the Rome Statute. The conflict in East Timor was however resolved before the Rome Statute came into force without retrospective application. 